\title{
Ayushman Bharat- India's answer to improve health problems among poor
}

\author{
Dr. Vagish Kumar L.S* \\ Department of Oral Medicine \& Radiology, Yenepoya Dental College and Hospital, Yenepoya (Deemed to be University), Mangalore- \\ 575018 , Karnataka, India
}

*Corresponding Author

Dr. Vagish Kumar L.S

\author{
Article History \\ Received: 20.06.2019 \\ Accepted: 13.07 .2019 \\ Published: 30.07 .2019
}

Abstract: Ayushman Bharat is a recently unveiled India's health protection scheme that aims to provide health benefits to 50 crore poor people. The article briefly discusses the schemes success and provides few directions to improve the existing scheme.

Keywords: India; Ayushman Bharat; Health; Insurance; Poor

\section{SHORT COMMUNICATION}

Ayushman Bharat is a national health protection scheme that approximately covers 50 crore beneficiaries who are poor and vulnerable [1]. That is to say that it covers $40 \%$ of the Indian population [1]. It provides coverage of 5 lakh rupees per family per year with no restriction of family size. People covered under this scheme can avail cashless treatment from any public/ private empanelled hospitals across the country [1].

Lack of financial resources is a major barrier in availing health services among poor families in India. This scheme provides the poor an access to quality health and medication, with timely treatment leading to improvement in health and quality of life among these people [1]. It is $60 \%$ funded by the Centre and $40 \%$ from states and is on its way to become the World's largest free healthcare scheme within 5 months of its launch [2]. It is reported that within 200 days of the scheme implementation, 3.07 crore people were issued the scheme cards and 20.8 lakh poor were benefitted with free treatment worth RS 5000 crores [3].

In Mumbai, 492 hospitals come under this Ayushman Bharat scheme and 31,823 surgeries mainly for heart failure and kidney dysfunction were performed [4]. 33 out of 36 states and Union Territories of India have signed MoUs with National Health Authority (NHA), which is in charge of the rollout, implementation and management of Ayushman Bharat Scheme [5]. The scheme defines 1,350 medical packages covering surgery, medical and daycare treatments including medicines, diagnostics and transport [5]. According to data available, $60 \%$ treatment under the scheme was carried out in private hospitals and $40 \%$ were carried out in public hospitals [5]. In Uttar Pradesh (UP), 3 million people were issued Ayushman Bharat scheme cards and on average 1000 patients were getting treatment under this scheme on daily basis [6]. Under this scheme approximately 1 lakh patients have already availed free medical treatment from the empanelled 1415 hospitals throughout the UP state [6].

The ruling party BJP manifestoes for 2019 reveals that it plans to upgrade the Ayushman Bharat scheme by establishing 1.5 lakh health and wellness centres to provision telemedicine and diagnostic laboratory facilities by 2022, to ensure delivery of quality primary medical care to the poor [7]. Washington DC-based Centre for Global Development (CGD), based on the first year performance of Ayushman Bharat Scheme, has analyzed the schemes effort overall as positive, and suggested that better purchasing policies for medical supplies and drugs together with improving access to primary care, and an increased focus on vaccines would make the scheme sustainable and provide the required high quality health care service to Indians [8]. Director General of World Intellectual Property Organization Francis Gurry has also praised the scheme which emphasizes the importance of innovation to health and congratulated Prime Minister Narendra Modi on this incredible success [9]. It is to be noted that the finance minister of India while presenting the interim budget, has assured to expand the Ayushman Bharat schemes coverage and increased its allocation two and a half times from Rs 2,400 crore in 2018-19 to Rs 6,400 crore for 2019-20 [10]. Also, the government in its interim budget has announced significant hike of $16 \%$ in the overall health budget from previous Rs $54,302.50$ crore to Rs 61,398 crore for

Copyright @ 2019: This is an open-access article distributed under the terms of the Creative Commons Attribution license which permits unrestricted use, distribution, and reproduction in any medium for non commercial use (NonCommercial, or CC-BY-NC) provided the original author and source are credited. 
the current 2019-2020 fiscal [11, 12]. According to latest available data, since its inception in September 2018, 26 lakh poor people have availed the benefits of this scheme [13].

The scheme will definitely be a huge success if its existing coverage is expanded and the list of procedures eligible increased, together with the ceiling associated with it. The scheme should also focus on delivering free health insurance with respect to primary health. Ayushman Bharat Scheme, if systematically financed and strictly monitored by the government, certainly gives millions of poor people in India a ray of hope to access the otherwise costlier health care system and lead a better life.

\section{REFERENCES}

1. India.gov.in. Ayushman Bharat. Available from:- https://www.india.gov.in/spotlight/ayushman-bharat-national-health-prote.... Last accessed on:- 16/05/2019.

2. The Economic Times. Ayushman Bharat on way to become world's largest free healthcare scheme: Arun Jaitley. March 6, 2019. Available from:-https://economictimes.indiatimes.com/industry/healthcare/biotech/healthc.... Last accessed on:-16/05/2019.

3. Mathew, J. C. (2019). Why Ayushman Bharat may stay irrespective of election outcome. Business Today. April 22. Available from:-https://www.businesstoday.in/top-story/why-ayushman-bharat-may-stay-irre.... Last accessed on:- May 16, 2019.

4. Sawant, A. (2019). AYUSHMAN BHARAT: Rural folks throng cities for govt health schemes. DNA. May 16, 2019. Available from:-https://www.dnaindia.com/mumbai/report-ayushman-bharat-rural-folks-thron.... Last accessed on:- May 16, 2019.

5. Mathew, J. C. (2019). BT Buzz: With or without Modi, 'achche din' ahead for Ayushman Bharat. Business Today. May 13, Available from:-https://www.businesstoday.in/bt-buzz/news/bt-buzz-modi-or-no-modi-achche.... Last accessed on:-May 16, 2019.

6. Rawat, V. S. (2019). BJP banking 'goodwill' of Ayushman Bharat scheme for electoral gains in UP. Business Standard. April 17. Available from:- https://www.business-standard.com/article/elections/bjp-banking-goodwill.... Last accessed on:- May 16, 2019.

7. The Economic Times. BJP manifesto highlights: The 75 promises for India. April 8, 2019. Available from:https://economictimes.indiatimes.com/news/elections/lok-sabha/bjps-sanka.... Last accessed on May 16, 2019.

8. Financial Express. 'Ayushman Bharat' significant step towards universal health coverage in India: US think tank. May 11, 2019. Available from:- https://www.financialexpress.com/india-news/ayushman-bharat-significant-... Last accessed on May 17, 2019.

9. Business Today. Francis Gurry praises PM Modi over success of Ayushman Bharat health scheme. January 18, 2019. Available from:- https://www.businesstoday.in/top-story/francis-gurry-praises-ayushman-bh.... Last accessed on May 18, 2019.

10. Dey, S. (2019). Ayushman Bharat scheme helped 10 lakh patients save Rs 3,000 crore: Piyush Goyal. February 1. Available from:- https://timesofindia.indiatimes.com/business/india-business/ayushman-bha.... Last accessed on May 18, 2019.

11. NDTV budget 2019. Rs. 61,398 Crore For Health Sector In Budget, Highest In Two Years. February 1, 2019. NDTV. Available from:- https://www.ndtv.com/business/budget-2019-rs-61-398-crore-for-health-sec.... Last accessed on May 18, 2019.

12. Business Standard. Centre allocates Rs 61,398 crore for health sector in Interim Budget 2019. February 1, 2019. Available from:https://www.business-standard.com/article/pti-stories/budget-rs-61-398-c.... Last accessed on May 18, 2019.

13. Press Trust of India. Around 26 lakh people have availed treatment under Ayushman Bharat scheme so far: Kovind. Business Standard. June 20, 2019. https://www.business-standard.com/article/pti-stories/around-26-lakh-people-have-availed-treatmentunder-ayushman-bharat-scheme-so-far-kovind-119062000457_1.html. Last accessed on June 22, 2019. 